\title{
The evaluation and treatment of primary intraocular lymphoma
}

\author{
Joseph A. Hanson ${ }^{1,2+}$, Daniela Alexandru ${ }^{2+*}$ and Daniela A. Bota ${ }^{1,2+}$ \\ *Correspondence: danielaa@uci.edu \\ ${ }^{\dagger}$ All authors contributed equally to this work. \\ 'Department of Neurology, University of California at Irvine, USA. \\ ${ }^{2}$ Department of Neurological Surgery, University of California at Irvine, USA.
}

\begin{abstract}
Primary intraocular lymphoma (PIOL) is a relatively rare form of Non-Hodgkin's Lymphoma arising in the lymphoid tissues of the eye. It is highly correlated with primary CNS lymphoma (PCNSL) and it is estimated that up to $80 \%$ of patients presenting with PIOL will eventually manifest intracranial malignancy, which is the largest contributor to mortality. Most patients present with nonspecific visual symptoms, including floaters and blurry vision, and are often initially diagnosed with uveitis or retinitis. Definitive diagnosis requires biopsy of malignant tissues with demonstration of malignant lymphoid cells. Optimal therapy is to this point undefined, and the available literature is limited to case reports and retrospective series. Currently employed therapies include the use of localized external beam radiation therapy (EBRT), whole brain radiation therapy (WBRT), systemic chemotherapy, intrathecal chemotherapy, and, most recently, direct intravitreal (IVT) chemotherapy. While radiation therapy and chemotherapy can produce a high response rate, they have not been shown to effectively prevent relapse or the incidence of CNS spread. Methotrexate has been the most popular therapy used for the treatment of intraocular lymphoma. It has been administered systemically, intrathecally or intravitreally. However due to multiple mechanisms of resistance developed by lymphoma cells against methotrexate, this drug has been unable to prevent disease recurrence. The newest, and perhaps most promising, reported therapy includes the use of rituximab anti-CD20 monoclonal antibody either alone or in combination chemotherapy via intrathecal or IVT administration. Most cases in the literature employ combinations of available therapies, and there are no comparative studies of significant power to date. Multicenter collaboration will be required to determine the true relative efficacy and adversity of the therapeutic options available.
\end{abstract}

keywords: Primary intraocular lymphoma, methotrexate, intravitreal rituximab

\section{Introduction}

Primary intraocular lymphoma (PIOL), also known as primary vitreoretinal lymphoma (PVRL), is a rare subset of primary central nervous system lymphoma (PCNSL) arising in the retina, vitreous, subretinal pigment epithelium, or optic nerve head [1]. Intraocular lymphoma can arise primarily within the lymphoid tissues of the eye or due to metastatic spread of hematopoietic malignancy from the CNS. The disease is classified as PIOL if, at the time of diagnosis, the disease is limited to the eye with no intracranial involvement [2]. Vitreoretinal lymphoma with concomitant CNS disease is classified as PCNSL with ocular involvement [2]. It has been shown that up to $80 \%$ of patients with PIOL will be subsequently diagnosed brain lymphoma, and among those presenting with PCNSL up to $25 \%$ have concomitant ocular involvement [3]. For this reason it is thought that definitive management of PIOL may improve morbidity and mortality by preventing spread to the brain and leptomeninges [4].

Given its rarity, PIOL has been difficult to study. To date, no formal standards exist for the treatment of this condition, but many therapies have been experimentally employed. For those with no concomitant CNS disease, high dose intravenous (IV) methotrexate with adjuvant local radiation $[5,6]$ and intraocular methotrexate injections [7-9] have been popular in the literature.
For those with comorbid CNS malignancy, whole brain radiation therapy (WBRT) and IV or intrathecal (IT) chemotherapy in conjunction with intravitreal chemotherapy have been used [10-12]. The most novel therapy for the treatment of PIOL involves the use of rituximab, a humanized antibody targeting CD20+ B cells, in either IV or intravitreal administration $[13,14]$. Because several treatment modalities have been reported in the literature, many authors have called for further research into the comparative effectiveness of the available treatments and the establishment of treatment guidelines thereof $[1,15,16]$. This paper provides an up-to-date review of the multiple interventions currently employed in PIOL management, and to our knowledge contains the most comprehensive meta-analysis of case reports and retrospective series of novel therapies to date. With this we hope to better guide further investigation into the comparative effectiveness of novel methods for treating PIOL.

\section{Incidence and Distribution}

$\mathrm{PIOL}$ is the most common lymphoma of the eye [17]. A 20-year retrospective study at a large Canadian hospital estimated the incidence of PIOL in British Columbia to be between 0.017-0.048 per 100,000 people between 1990 and 2010 [18]. Still, since no national registry or central database for intraocular lymphoma exists, the true incidence of PIOL is unknown. PCNSL is both

(c) 2013Alexandru et al; licensee Herbert Publications Ltd. This is an Open Access article distributed under the terms of Creative Commons Attribution License (http://creativecommons.org/licenses/by/3.0). This permits unrestricted use, distribution, and reproduction in any medium, provided the original work is properly cited. 
more common and more closely monitored, and thus easier to quantify [19]. The Central Brain Tumor Registry of the United States (CBTRUS) published the incidence PCNSL in the U.S. as 0.46 per 100,000 person-years between 2004-2007 and 0.45 per 100,000 person-years between 2005-2009 [19,20]. Multiple case series have published a rate of $15-25 \%$ for PIOL in patients with PCNSL $[17,21-23]$. Chan et al., combined the case reports and the CBTRUS data and estimated that, between 2005 and $2009,20 \%$ of the 1,355 annual cases of CNS lymphoma included intraocular involvement [17]. Therefore, approximately 271 new cases of PIOL occur in conjunction with PCNSL each year in the United States [17]. It is proposed that the number of individuals diagnosed with PIOL without other CNS involvement on presentation ranges from 33 to 50 annually $[2,17]$. Based on these data, it is reasonable to conclude that the number of total new cases of PIOL in the United States approaches 300 cases per year.

The reported incidence of PCNSL, and consequently the incidence of PIOL, in the literature increased between the 1970 s to the1990s [24]. Recent evidence, however, suggests that the rate of PCNSL diagnosis has flattened, or even begun to decrease [25]. As noted above, the incidence of PCNSL per the CBTRUS has remained stable at 0.45-.046 per 100,000 person-years [19]. As noted by Chan et al., data from 1990-1994 showed an incidence of 0.43+/- 0.02 per 100,000 person-years, suggesting no change over the most recent two decades $[17,26]$. Other sources indicate that incidence has decreased since the 1990's, and is attributable to the decreased of HIV-related immune deficiency in the advent of effective antiretroviral therapy [27]. We conclude from these data that there is currently insufficient evidence to demonstrate that the incidence of PIOL has significantly changed in recent decades.

The most important risk factors for PCNSL are HIV status and Epstein-Barr virus infection status $[\mathbf{2 8 , 2 9 ]}$. There are no other known risk-factors for PCNSL or PIOL, though there have been reported cases of PIOL secondary to ocular toxoplasmosis [30].

\section{Diagnosis and Differential Diagnosis}

Diffuse Large B-Cell Lymphoma (DLBCL) is the most common systemic lymphoma, and makes up 31\% of all Non-Hodgkin's Lymphoma (NHL) [25]. Among PCNSL, upward of $90 \%$ are comprised of DLBCL, with the remainder comprised of undifferentiated lymphoma, T-cell lymphoma, and Burkitt lymphoma such that up to $98 \%$ are classified as some form of $\mathrm{NHL}[31,32]$.

The literature reports anywhere between $60-90 \%$ of patients present with bilateral PIOL $[2,21]$. The majority of patients that present with ocular involvement will later develop CNS involvement as well [11]. Chan et al., reported that $54 \%$ of the patients in their case series had PCNSL [17]. Cassoux et al., found that $66 \%$ of their PIOL patients developed PCNSL over time [33]. The average reported rate for PCNSL development in PIOL patients ranges from $50-80 \%[11,17,33]$.
The presenting symptoms of patients with $\mathrm{PIOL}$ are nonspecific and benign. Patients often complain of seeing floaters or blurred vision 1-2 years prior to diagnosis $[4,17]$. As the disease progresses, it can mimic the inflammation of uveitis and is often inappropriately treated with corticosteroids $[4,34,35]$. Although there is evidence that measurable differences in the ratios of interleukin- 6 , interleukin-10, and interferon- $\gamma$ may allow for the differentiation between inflammatory uveitis and lymphomatous uveitis, only elevations in IL-10 are typically measured in clinical practice and these have not proven sensitive or specific [36]. Occasionally, PIOL has been reported to mimic viral retinitis, and has been treated with antiviral medication [37].

Ophthalmoscopic examination may reveal perivascular sheathing similar in appearance to vasculitis [21]. Patients can also have salmon-colored deposition resembling peripheral drusen or fundus flavimaculatus [21].

Definitive diagnosis of PIOL requires identification of malignant lymphoid cells from ocular tissue or CSF [38]. Several techniques exist to obtain the required tissue, including: aqueous aspiration of the vitreous fluid, diagnostic vitrectomy, diagnostic retinal biopsy, diagnostic choroidal biopsy, or diagnostic enucleation as the case requires $[12,17,34,38,39]$. The workup should include chest radiography, complete blood count, erythrocyte sedimentation rate, and routine blood chemistries to rule out other sources of inflammatory uveitis, as well as complete neurologic examination, brain CT and MRI [39]. Lumbar puncture to evaluate CSF for atypical lymphoid cells in order to rule out concomitant CNS malignancy is important [39]. Positive cells in the CSF will indicate leptomeningeal disease, which is present in up to $42 \%$ of patients with PCNSL and indicates the use of a therapeutic regimen with high CNS penetration $[40,41]$.

\section{Treatment}

Treatment regimens for PCNSL can be broadly grouped into two categories: systemic and local. Generally, the prevailing consensus is to employ local therapies for restricted ocular disease $(\mathrm{PIOL})$ and to reserve systemic therapy for those with CNS disease $[1,15,17]$. Local therapy is typically considered the intervention of choice when thorough neurologic workup is non-revealing in light of a histological diagnosis of intraocular lymphoma [17]. The goal of local therapy is to both eradicate intraocular disease and prevent subsequent spread to the CNS [11]. Most authors, including Chan et al., recommend a multidisciplinary approach in treating $\mathrm{PIOL}$ with input from a collaborative team of neuro-oncologists and ophthalmologists [42].

While some large case series have reported no difference in disease progression when comparing systemic versus local therapy, there have been no conclusive results to this effect $[1,17]$. Local therapy typically involves either local radiation therapy or IVT methotrexate, whereas systemic therapies include WBRT, systemic chemotherapy, or intrathecal 
Hanson et al. Journal of Cancer Therapeutics and Research 2013, http://www.hoajonline.com/journals/pdf/2049-7962-2-15.pdf

Table 1. Radiotherapy and Chemotherapy for Primary Intraocular Lymphoma.

\begin{tabular}{|c|c|c|c|c|c|c|c|c|}
\hline Author & Therapy & Eyes Treated & Primary Endpoint & $\begin{array}{l}\text { Median Overall } \\
\text { Survival }\end{array}$ & Response Rate & Relapse Rate & & $\begin{array}{l}\text { Median } \\
\text { Follow-up }\end{array}$ \\
\hline $\begin{array}{l}\text { Margolis et al., } \\
{[44]}\end{array}$ & WBRT & 13 & Remission Duration & 12 months & $69 \%$ & $22 \%$ & 7.5 months & 24 months \\
\hline $\begin{array}{l}\text { Hoffman et al., } \\
{[46]}\end{array}$ & $\begin{array}{l}\text { WBRT; IV/IT } \\
\text { CHOP, EPOCH and/ } \\
\text { or MTX }\end{array}$ & 18 & Survival & 16 months & - & $79 \%$ & 14.5 months & - \\
\hline $\begin{array}{l}\text { Mikami et al., } \\
\text { [47] }\end{array}$ & EBRT & 22 & 3-Year Survival & $\begin{array}{l}89 \% \text { at } 36 \\
\text { months }\end{array}$ & $95 \%$ & $55 \%$ & 28 months & 36 months \\
\hline $\begin{array}{l}\text { Hormigo } \\
\text { et al., [4] }\end{array}$ & $\begin{array}{l}\text { EBRT; WBRT; IV } \\
\text { MTX, VCR, PCB, } \\
\text { CHOP and/or Ara-C }\end{array}$ & 17 & Survival & 39 months & $82 \%$ & $79 \%$ & 16.5 months & - \\
\hline $\begin{array}{l}\text { Isobe et al., } \\
{[45]}\end{array}$ & $\begin{array}{l}\text { EBRT; PCI; } \\
\text { IV HD-MTX, } \\
\text { MTX or CHOP }\end{array}$ & 15 & Survival & 41 months & $87 \%$ & - & - & - \\
\hline $\begin{array}{l}\text { Sandor et al., } \\
{[50]}\end{array}$ & $\begin{array}{l}\text { IV HD-MTX, } \\
\text { TTP, VCR, DXS; } \\
\text { IT Ara-C, MTX }\end{array}$ & 14 & Survival & $\begin{array}{l}68.8 \% \text { at } 54 \\
\text { months }\end{array}$ & $79 \%$ & $36 \%$ & - & - \\
\hline $\begin{array}{l}\text { Batchelor } \\
\text { et al.,[52] }\end{array}$ & HD-MTX & 9 & Remission Duration & - & $44 \%$ & $43 \%$ & 17 months & \\
\hline $\begin{array}{l}\text { Smith et al., } \\
\text { [56] }\end{array}$ & $\begin{array}{l}\text { IVT MTX; IV } \\
\text { cyclophosphamide, } \\
\text { procarbazine, } \\
\text { MTX, VP-16 or } \\
\text { Ara-C }\end{array}$ & 26 & $\begin{array}{l}\text { Safety, Response } \\
\text { Rate }\end{array}$ & $\begin{array}{l}62.5 \% \text { at } 18.5 \\
\text { months }\end{array}$ & $100 \%$ & - & - & $\begin{array}{l}18.5 \\
\text { months }\end{array}$ \\
\hline $\begin{array}{l}\text { Frenkel et al., } \\
{[8]}\end{array}$ & IVT MTX & 44 & $\begin{array}{l}\text { Safety, Response } \\
\text { Rate }\end{array}$ & - & $100 \%$ & $48 \%$ & 17 months & $\begin{array}{l}16.2 \\
\text { months }\end{array}$ \\
\hline
\end{tabular}

WBRT, whole brain radiation therapy; IV, intravenous; IT, intrathecal; CHOP, cyclophosphamide, doxorubicin, vincristine and prednisone; $\mathrm{EPOCH}$, etoposide, doxorubicin, vincristine, cyclophosphamide, and prednisone; MTX, methotrexate; VCR, vincristine; PCB, procarbazine; Ara-C, cytarabine; EBRT, external beam radiation therapy; PCI, prophylactic cranial irradiation; HD-MTX, high dose methotrexate; TTP, thiotepa; DXS, dexamethasone; IVT, intravitreal; VP-16, etoposide.

chemotherapy. Here we will compile the available literature in order to review the progress made thus far towards defining optimal therapy in PIOL and PCNSL with ocular involvement, detailing advances in radiation therapy, chemotherapy, and biological therapy.

\section{Radiation Therapy}

Early local interventions for PIOL primarily involved radiation monotherapy [43] Margolis et al., originally advocated WBRT as the primary intervention due to potentially beneficial effects on the high co-incidence of CNS malignancy [44]. Since that time, there has been broader acceptance of local therapy, which seeks to avoid the high rate of relapse observed in systemic chemotherapies and the high morbidity associated with WBRT and its well-known association with radiation leukoencephalopathy [11].

Localized external beam radiation therapy (EBRT) involves exposure to the entirety of both eyes without brain exposure and has become the radiation modality of choice in the absence of CNS malignancy [17]. Dosing typically entails a total of 35-50 Gy delivered in 1.5-2.0 Gy fractions using a pair of lateral opposed fields of photon beams $[11,17,45]$. Reports indicate that rates of visually significant radiation-induced retinopathy are low in patients undergoing EBRT, and that typically no attempt is made to spare the lens given the risk of missing malignancy in the anterior vitreous and the ease of surgical cataract repair $[4,5,45]$. However, Pe'er et al., postulate that the true incidence of radiation retinopathy is likely masked by patient mortality and the resulting short follow-up period status-post treatment [11]. Other adverse events noted in the literature include: conjunctivitis, dry eyes, punctate keratopathy, vitreous hemorrhage, optic atrophy,

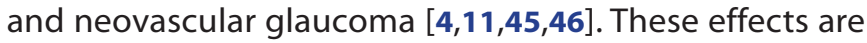
reportedly rare, however, as Mikami et al., utilized radiation monotherapy in 22 immunocompetent patients over a 12 year time period and described cataract formation as the only major adverse development [47]. Although they achieved $95 \%$ local control at 3 years of follow-up, $55 \%$ of patients experience intracranial relapse of disease at a median of 28 months after treatment [47].

Most groups now advocate combination therapy, employing both EBRT and systemic or intrathecal chemotherapy, primarily methotrexate based, to enhance the response to irradiation $[11,48]$. With this method the results have been modest, with none of the reviewed literature showing complete response in all treated eyes (Table 1). Margolis et al., reported complete remission in 9/13 eyes with recurrence in 2/9 eyes using WBRT [44]. Hoffman et al., reported $21 \%$ survival of the 14 patients 
in series with all but 1 of the surviving suffering relapse [46]. Hormigo et al., used EBRT/WBRT or combination radiotherapy and systemic methotrexate based chemotherapy in 13 eyes, reporting complete remission in 10/13 eyes with partial response in $1 / 13$ and CNS relapses in 2 patients responding to therapy [4]. Isobe et al., reported complete remission in $13 / 15$ patients with using a combination of EBRT, systemic chemotherapy, and prophylactic cranial irradiation (PCI), but found that $\mathrm{PCl}$ did not affect intracranial recurrence [45]. However, when Berenbom et al., performed a chart review of 12 patients and 21 eyes affected by PIOL, they noted that 7/7 patients receiving EBRT with or without chemo experienced no recurrence whereas $2 / 4$ receiving chemo alone did suffer a recurrence [5]. Although this study was retrospective and non-controlled with a small sample size, it does suggest, as Berenbom and colleagues point out, that EBRT may yet be seen as a first-line therapy in PIOL [5].

\section{Chemotherapy}

Demonstrating an effective and appropriate chemotherapeutic regimen for PIOL has been made difficult by the rarity of the diagnosis and the multitude of the pharmacologic interventions available. One case series alone employed multiple combinations of 10 chemotherapies in 11 patients, demonstrating the haphazard approach utilized in the majority of the literature [49]. Of the available chemotherapeutic options, the most commonly reported for the treatment of PIOL included some combination of methotrexate, thiotepa, vincristine, dexamethasone, cytarabine, CHOP (cyclophosphamide, doxorubicin/Adriamycin, vincristine, and prednisolone), cisplatin, temozolomide, and EPOCH (etoposide, prednisolone, vincristine, cyclophosphamide, and doxorubicin). As mentioned above, in a retrospective chart review, Hoffman et al., demonstrated that $21 \%$ of patients treated with a combination of radiotherapy and a complex chemotherapy regimen (involving combinations of $\mathrm{CHOP}$, methotrexate, dexamethasone, cytarabine, cisplatin, and EPOCH) achieved 5-year survival [46].

High dose methotrexate (HD-MTX) in IV or intrathecal administration is currently the most commonly utilized therapy for PIOL and PCNSL with ocular involvement in the US [11]. Methotrexate-based chemotherapy is now generally considered to be the best first line therapy for chemotherapynaïve PIOL patients, and is the recommended treatment by prominent authors [42]. Sandor et al., demonstrated the efficacy of systemic chemotherapy alone with a combination of high dose $\left(8.4 \mathrm{~g} / \mathrm{m}^{2}\right)$ IV methotrexate with leucovorin rescue, thiotepa, vincristine, dexamethasone, and intrathecal cytarabine and methotrexate in 14 nonimmunocompromised patients. They reported $100 \%$ response rate but with high relapse rate, with $5 / 14$ patients relapsing within 4.5 years of follow-up [50]. Given these findings, most authors recommend against systemic chemotherapy alone in the management of PIOL, instead suggesting a combination radiotherapy and chemotherapy approach due to the high relapse rate of chemotherapy alone [51].

Batchelor et al., employed high dose $\left(8 \mathrm{~g} / \mathrm{m}^{2}\right)$ IV methotrexate monotherapy in 9 patients and demonstrated the presence of micromolar concentrations in both the vitreous and the aqueous fluid, with lower levels present in the vitreous in $5 / 6$ patients in whom both chambers were assayed. 4/9 patients experienced sustained remission, and of those that relapsed, two demonstrated micromolar concentrations of methotrexate in the vitreous fluid. The authors hypothesized that the low penetration into the vitreous may be responsible for the high relapse rate of PIOL in treated patients [52]. To this end, Henson et al., demonstrated the vitreous humor levels of methotrexate to be $100 x$ lower than the serum concentration and 10x lower than the aqueous humor concentration 4 hours after HD-MTX infusion, the timing of peak concentration in the vitreous fluid in animal models $[53,54]$.

Following these findings, the application of intravitreal (IVT) injections of methotrexate to obtain high target-tissue concentrations became more popular. Fishburne et al., were the first to trial this therapy in 1997, reporting that after over a year of weekly $400 \mathrm{pg}$ injections only $1 / 7$ eyes treated suffered from significant loss of vision and none experienced any ocular toxic reaction [55]. De Smet and colleagues performed vitreous samplings after IVT injections of methotrexate, finding that the vitreous eliminates methotrexate by firstorder kinetics, and that IVT injections allowed for prolonged tumoricidal concentrations in the target tissue [7]. Smith et al., put these findings to the test, employing IVT injections of $400 \mu \mathrm{g}$ in 26 eyes [56]. They found clearance of malignant cells in 26/26 eyes after a maximum of 12 injections but did not make comment on relapse rate or changes in life expectancy. Common complications included cataracts, corneal epitheliopathy, vitreous hemorrhage, optic atrophy, and sterile endophthalmitis [56]. The largest study to date of the efficacy and safety of IVT methotrexate for PIOL was performed by Frenkel et al., In a 10-year retrospective study, Frenkel and colleagues treated 44 eyes with IVT therapy and found that $95 \%$ were cleared of malignant cells with 13 or less injections, and $100 \%$ were cleared of malignant cells after 25 injections [8]. While $14 / 29$ patients succumbed to systemic or CNS lymphoma with a median of 17 months status-post trial, the authors report zero ocular recurrence in a follow-up time of 3 years [8].

However, as IVT methotrexate has become more popular, reports of resistance to IVT methotrexate have begun to surface. In a case report of a patient with recurrent PIOL, Sen et al., employed immunocytohistochemistry to demonstrate aberrations in multi-drug resistance protein intraocular lymphoma cells [57]. The researchers also found that decreased reduced folate carrier proteins and reduced levels of folate binding protein (FBP) among intraocular lymphoma cells [57]. The mechanisms employed by lymphoma cells to resist methotrexate therapy are quite varied. Once methotrexate 
enters the cell it becomes polyglutamated, a form which is a potent inhibitor of dihydrofolate reductatase (DHFR) [58]. These polyglutamated forms of methotrexate are broken down to the monoglutamated form in the lysosomes by the enzyme $\gamma$-glutamyl hydrolase and thus effused from the cell [58]. Bertino et al., described that alterations in each step of this process can lead to resistance to methotrexate therapy [58]. Five general mechanisms of resistance have been described in the literature [58-61]. The first mechanism is impaired transport of methotrexate across the cellular membrane. The second mechanism is decrease or lack of polyglutamation [58]. The third mechanism is increase in DHFR [58]. The fourth mechanism is consistent with mutated DHFR which leads less biding of methotrexate [58]. The fifth mechanism described in the literature is the increased level of lysosomal enzyme $\gamma$-glutamyl hydrolase, which hydrolyses the glutamated methotrexate quicker and leads to faster excretion from the cell [58]. Drug resistance is also mediated by tumor suppressor genes. Research has showed that acute lymphocytic leukemia cells with mutated p53 gene can undergo gene amplification after exposure to methotrexate $[\mathbf{5 8 , 6 0}]$. All these mechanisms of resistance lead to a high failure rate of the IV methotrexate therapy. Therefore, in conjunction with the large majority of patients that also suffer from CNS or systemic lymphoma, the salience of IV methotrexate for PIOL treatment, in isolation, towards extending life expectancy is questionable.

\section{Rituximab}

Rituximab is a monoclonal mouse-human chimaeric lgG1-K antibody that binds to the CD20 antigen, which is found on mature B lymphocytes [62]. Studies investigating Rituximab in combination therapy for systemic aggressive $\mathrm{NHL}$ were promising, leading to the investigation of rituximab as a potential tool in the treatment of PIOL and PCNSL $[62,63]$. Batchelor and colleagues led the largest study to date employing IV rituximab $\left(375 \mathrm{mg} / \mathrm{m}^{2}\right)$ in 12 patients that had failed methotrexate therapy, demonstrating response in $5 / 12$ patients in this difficult patient population [64].

Rituximab cannot easily cross the blood-brain barrier (BBB), however, and recent pharmacological studies have demonstrated that CNS levels of rituximab are approximately $0.1 \%$ of serum levels after IV administration of the drug $[64,65]$. While there are some reports of demonstrable effects of IV rituximab therapy likely secondary to localized disruption of the BBB at the tumor site, other authors have demonstrated that IV administration does not impact the rate of CNS relapse $[64,66]$. Phase I trials have demonstrated the tolerable administration of rituximab via the intrathecal route employing an Ommaya reservoir at $10 \mathrm{mg}$ and $25 \mathrm{mg}$ dose levels, leading to the broader study of rituximab as mono- and combination therapy for PCNSL [65]. More recent investigation has demonstrated the safety of intraocular injections of rituximab at $1 \mathrm{mg}$ dosage in animal models and humans $[67,68]$. Furthermore, animal models have demonstrated that
IVT rituximab injections fully penetrate the retina with a halflife of 4.7 days in both the vitreous and aqueous fluid, and are thus effective at reaching target tissues in PIOL $[69,70]$. Mineo et al., demonstrated the efficacy of intravitreal and intracerebral rituximab injections in mice transfected with lymphomatous CD20 positive $B$ cells, reporting that over half the mice injected with rituximab demonstrated total eradication of graft cells and the remaining half all demonstrated inhibition of tumor progression [71]. This has lead to a significant speculation regarding the potential future role of rituximab in treating PIOL and ocular recurrence in PCNSL, though the data of such efficacy is limited thus far.

Most data regarding the efficacy of rituximab in treating PIOL currently comes from case reports and a few retrospective case series. Vosganian et al., report treating a 65 year old woman with IV methotrexate $\left(4 \mathrm{~g} / \mathrm{m}^{2}\right)$ and IV rituximab $\left(500 \mathrm{mg} / \mathrm{m}^{2}\right)$ followed by a total of $36 \mathrm{~Gy}$ EBRT with complete remission for 16 months, at which point she progressed to PCNSL [72]. Turaka et al., report treating one patient with bilateral PIOL with IVT methotrexate ( $500 \mu \mathrm{g}$ dose) and IVT rituximab ( $1 \mathrm{mg}$ dose) who experienced complete remission [73]. Yeh et al., report a case of an 83 year old woman with PIOL treated with combination IVT rituximab (1 $\mathrm{mg}$ dose) and methotrexate (400 $\mu \mathrm{g}$ dose); the patient was reported to be in complete remission with no progression to CNS involvement or relapse at 18 months follow-up [14]. Although these authors express optimism for the use of rituximab in PIOL, little can be made from these case reports alone. These results do, however, further emphasize the need for prospective investigation into the competing treatments for PIOL.

Hashida et al., reported the largest series to date featuring IVT rituximab. They describe treating 20 eyes of 13 patients who had already demonstrated adverse effects from IVT methotrexate with $1 \mathrm{mg}$ IVT injections of rituximab monotherapy. They reported ocular recurrence in 11/20 eyes after a follow-up interval of three months, but describe that ocular lesions "improved" in 13/13 patients but that CNS progression occurred in $9 / 13$ patients over the full follow-up period of 31 months [74]. As many of the featured authors have stated, the appropriate dosage and treatment regimen for rituximab in PIOL and PCNSL is still unknown and should be considered an experimental, if promising, therapeutic option for the rare patients that present for clinical trials for this rarer still disease (Table 2).

\section{Conclusion}

Though no standardized recommendation exists for the treatment of PIOL or PCNSL with ocular involvement, huge advances have been made in the past three decades. The efficacy of combined radiotherapy and chemotherapy has been put to the test in the most feasible method possible for such a rare condition, and numerous scientific advances have allowed for the detection and injection of chemotherapeutic agents directly within the vitreous fluid. The advent of biologics 
Hanson et al. Journal of Cancer Therapeutics and Research 2013,

http://www.hoajonline.com/journals/pdf/2049-7962-2-15.pdf

doi: 10.7243/2049-7962-2-15

Table 2. Rituximab in the Treatment of Primary Intraocular Lymphoma.

\begin{tabular}{|c|c|c|c|c|c|c|c|c|}
\hline Author & Route & Dose & Combination & Eyes Treated & Response Rate & Relapse Rate & Median Relapse & Median Follow-up \\
\hline Batchelor et al., [60] & IV & $375 \mathrm{mg} / \mathrm{m}^{2}$ & - & PCNSL & $5 / 12$ & $4 / 5$ & 19 months & 64.3 months \\
\hline Vosganian et al., [68] & IV & $500 \mathrm{mg} / \mathrm{m}^{2}$ & HD-MTX, EBRT & 1 & $1 / 1$ & $1 / 1$ & 16 months & 19 months \\
\hline Turaka et al., [69] & IVT & $1 \mathrm{mg}$ & IVT MTX & 2 & $2 / 2$ & $0 / 2$ & - & 33.5 moths \\
\hline Yeh et al., [14] & IVT & $1 \mathrm{mg}$ & IVT MTX & 1 & $1 / 1$ & $0 / 1$ & - & 18 months \\
\hline
\end{tabular}

IV, intravenous; IVT, intravitreal; HD-MTX, high dose methotrexate; EBRT, external beam radiation therapy; MTX, methotrexate;

PCNSL, primary central nervous system lymphoma.

like rituximab sparks a great hope in the community for a targeted and efficacious therapy. Some experts theorize that individually-tailored medicine is the future of the treatment for $\mathrm{PIOL}$, and that genomics will play a role in treatment choice as time progresses [75]. For now, we report the facts as they are regarding the previous standards of PIOL care and express our own optimism regarding the efficacy of intravitreal therapy, specifically with rituximab. We join with expert opinion in calling for multicenter collaboration in the development of comparative studies to determine the true relative efficacy and adversity of the therapeutic options available.

\section{Competing interests}

The authors declare that they have no competing interests.

Publication history

Received: 29-Jan-2013 Revised: 19-Mar-2013

Re-Revised: 10-Apr-2013 Accepted: 19-Apr-2013

Published: 27-Apr-2013

\section{References}

1. Grimm SA, Pulido JS, Jahnke K, Schiff D, Hall AJ, Shenkier TN, Siegal T, Doolittle ND, Batchelor T, Herrlinger U, Neuwelt EA, Laperriere N, Chamberlain MC, Blay JY, Ferreri AJ, Omuro AM, Thiel E and Abrey LE: Primary intraocular lymphoma: an International Primary Central Nervous System Lymphoma Collaborative Group Report. Ann Oncol 2007, 18:1851-5. | Article | PubMed

2. Levy-Clarke GA, Chan CC and Nussenblatt RB: Diagnosis and management of primary intraocular lymphoma. Hematol Oncol Clin North Am 2005, 19:739-49, viii. | Article | PubMed

3. Peterson K, Gordon KB, Heinemann MH and DeAngelis LM: The clinical spectrum of ocular lymphoma. Cancer 1993, 72:843-9. | PubMed

4. Hormigo A, Abrey L, Heinemann MH and DeAngelis LM: Ocular presentation of primary central nervous system lymphoma: diagnosis and treatment. BrJ Haematol 2004, 126:202-8. | Article | PubMed

5. Berenbom A, Davila RM, Lin HS and Harbour JW: Treatment outcomes for primary intraocular lymphoma: implications for external beam radiotherapy. Eye (Lond) 2007, 21:1198-201. | Article | PubMed

6. Stefanovic A, Davis J, Murray T, Markoe A and Lossos IS: Treatment of isolated primary intraocular lymphoma with high-dose methotrexatebased chemotherapy and binocular radiation therapy: a singleinstitution experience. Br J Haematol 2010, 151:103-6. | Article | PubMed Abstract | PubMed Full Text

7. de Smet MD, Vancs VS, Kohler D, Solomon D and Chan CC: Intravitreal chemotherapy for the treatment of recurrent intraocular lymphoma. Br J Ophthalmol 1999, 83:448-51. | Article | PubMed Abstract | PubMed Full Text

8. Frenkel S, Hendler K, Siegal T, Shalom E and Pe'er J: Intravitreal methotrexate for treating vitreoretinal lymphoma: 10 years of experience. Br J Ophthalmol 2008, 92:383-8. | Article | PubMed
9. Sou R, Ohguro N, Maeda T, Saishin Y and Tano Y: Treatment of primary intraocular lymphoma with intravitreal methotrexate. Jpn J Ophthalmol 2008, 52:167-74. | Article | PubMed

10. Nakauchi $Y$, Takase $H$, Sugita S, Mochizuki M, Shibata S, Ishiwata $Y$, Shibuya $Y$, Yasuhara M, Miura $O$ and Arai A: Concurrent administration of intravenous systemic and intravitreal methotrexate for intraocular lymphoma with central nervous system involvement. Int J Hematol 2010, 92:179-85. | Article | PubMed

11. Pe'er J, Hochberg FH and Foster CS: Clinical review: treatment of vitreoretinal lymphoma. Ocul Immunol Inflamm 2009, 17:299-306. I Article | PubMed

12. Rajagopal $R$ and Harbour JW: Diagnostic testing and treatment choices in primary vitreoretinal lymphoma. Retina 2011, 31:435-40. | Article | PubMed

13. Itty S and Pulido JS: Rituximab for intraocular lymphoma. Retina 2009, 29:129-32. | Article | PubMed

14. Yeh $S$ and Wilson DJ: Combination intravitreal rituximab and methotrexate for massive subretinal lymphoma. Eye (Lond) 2010, 24:1625-7. | Article | PubMed

15. Jahnke K, Thiel E, Abrey LE, Neuwelt EA and Korfel A: Diagnosis and management of primary intraocular lymphoma: an update. Clin Ophthalmol 2007, 1:247-58. | Article | PubMed Abstract | PubMed Full Text

16. Nussenblatt RB, Chan CC, Wilson WH, Hochman J and Gottesman $M$ : International Central Nervous System and Ocular Lymphoma Workshop: recommendations for the future. Ocul Immunol Inflamm 2006, 14:139-44. | Article | PubMed Abstract | PubMed Full Text

17. Chan CC, Rubenstein JL, Coupland SE, Davis JL, Harbour JW, Johnston PB, Cassoux N, Touitou V, Smith JR, Batchelor TT and Pulido JS: Primary vitreoretinal lymphoma: a report from an International Primary Central Nervous System Lymphoma Collaborative Group symposium. Oncologist 2011, 16:1589-99. | Article | PubMed Abstract | PubMed Full Text

18. Levasseur SD, Wittenberg LA and White VA: Vitreoretinal lymphoma: a 20-year review of incidence, clinical and cytologic features, treatment, and outcomes. JAMA Ophthalmol 2013, 131:50-5. | Article | PubMed

19. Dolecek TA, Propp JM, Stroup NE and Kruchko C: CBTRUS statistical report: primary brain and central nervous system tumors diagnosed in the United States in 2005-2009. Neuro Oncol 2012, 14 Suppl 5:v1-49. | Article I PubMed

20. States CBTRotU. CBTRUS statistical report: primary brain and central nervous system tumors diagnosed in the United States in 2004-2007. Central Brain Tumor Registry of the United States Hinsdale, IL; 2010. | website

21. Coupland SE and Damato B: Understanding intraocular lymphomas. Clin Experiment Ophthalmol 2008, 36:564-78. | Article | PubMed

22. Davis JL: Intraocular lymphoma: a clinical perspective. Eye (Lond) 2013, 27:153-62. | Article | PubMed

23. Hong JT, Chae JB, Lee JY, Kim JG and Yoon YH: Ocular involvement in patients with primary CNS lymphoma. J Neurooncol 2011, 102:139-45. | Article | PubMed

24. Olson JE, Janney CA, Rao RD, Cerhan JR, Kurtin PJ, Schiff D, Kaplan RS and $O$ 'Neill BP: The continuing increase in the incidence of primary central nervous system non-Hodgkin lymphoma: a surveillance, epidemiology, and end results analysis. Cancer 2002, 95:1504-10. | Article | PubMed

25. Batchelor T and Loeffler JS: Primary CNS lymphoma. J Clin Oncol 2006, 
24:1281-8. | Article | PubMed

26. Surawicz TS, McCarthy BJ, Kupelian V, Jukich PJ, Bruner JM and Davis FG: Descriptive epidemiology of primary brain and CNS tumors: results from the Central Brain Tumor Registry of the United States, 1990-1994. Neuro Oncol 1999, 1:14-25. | Article | PubMed Abstract | PubMed Full Text

27. Kadan-Lottick NS, Skluzacek MC and Gurney JG: Decreasing incidence rates of primary central nervous system lymphoma. Cancer 2002, 95:193-202. | Article | PubMed

28. Ambinder RF: Epstein-Barr virus associated lymphoproliferations in the AIDS setting. Eur J Cancer 2001, 37:1209-16. | Article | PubMed

29. So YT, Beckstead JH and Davis RL: Primary central nervous system lymphoma in acquired immune deficiency syndrome: a clinical and pathological study. Ann Neurol 1986, 20:566-72. | PubMed

30. Sauer TC, Meyers SM, Shen D, Vegh S, Vygantas C and Chan CC: Primary intraocular (retinal) lymphoma following ocular toxoplasmosis. Retin Cases Brief Rep 2010, 4:160-163. | Article | PubMed Abstract | PubMed Full Text

31. Giuliari GP, Hinkle DM and Foster CS: Local treatment for lymphoid malignancies of the eye. Anticancer Agents Med Chem 2009, 9:1123-8. I Article | PubMed

32. Miller DC, Hochberg FH, Harris NL, Gruber ML, Louis DN and Cohen $\mathrm{H}$ : Pathology with clinical correlations of primary central nervous system non-Hodgkin's lymphoma. The Massachusetts General Hospital experience 1958-1989. Cancer 1994, 74:1383-97. | PubMed

33. Cassoux N, Merle-Beral H, Leblond V, Bodaghi B, Milea D, Gerber S, Fardeau C, Reux I, Xuan KH, Chan CC and LeHoang P: Ocular and central nervous system lymphoma: clinical features and diagnosis. Ocul Immunol Inflamm 2000, 8:243-50. | Article | PubMed

34. Gonzales JA and Chan CC: Biopsy techniques and yields in diagnosing primary intraocular lymphoma. Int Ophthalmol 2007, 27:241-50. | Article | PubMed Abstract | PubMed Full Text

35. Read RW, Zamir E and Rao NA: Neoplastic masquerade syndromes. Surv Ophthalmol 2002, 47:81-124. | Article | PubMed

36. Fisson S, Ouakrim H, Touitou V, Baudet S, Ben Abdelwahed R, Donnou S, Miloudi A, Galand C, Bodaghi B, Lehoang P, Brissard M, Le GarffTavernier M, Fridman WH, Sautes-Fridman C, Cassoux N and Merle-Beral $\mathrm{H}$ : Cytokine profile in human eyes: contribution of a new cytokine combination for differential diagnosis between intraocular lymphoma or uveitis. PLoS One 2013, 8:e52385. | Article | PubMed Abstract | PubMed Full Text

37. de Smet MD, Nussenblatt RB, Davis JL and Palestine AG: Large cell lymphoma masquerading as a viral retinitis. Int Ophthalmol 1990, 14:413-7. | Article | PubMed

38. Sen HN, Bodaghi B, Hoang PL and Nussenblatt R: Primary intraocular lymphoma: diagnosis and differential diagnosis. Ocul Immunol Inflamm 2009, 17:133-41. | Article | PubMed Abstract | PubMed Full Text

39. Chan CC and Wallace DJ: Intraocular lymphoma: update on diagnosis and management. Cancer Control 2004, 11:285-95. | PubMed Abstract | PubMed Full Text

40. Balmaceda C, Gaynor JJ, Sun M, Gluck JT and DeAngelis LM: Leptomeningeal tumor in primary central nervous system lymphoma: recognition, significance, and implications. Ann Neurol 1995, 38:202-9. | Article | PubMed

41. Kesari S and Batchelor TT: Leptomeningeal metastases. Neurol Clin 2003, 21:25-66. | Article | PubMed

42. Chan CC and Sen HN: Current concepts in diagnosing and managing primary vitreoretinal (intraocular) lymphoma. Discov Med 2013, 15:93100. | Article | PubMed

43. Simon JW and Friedman AH: Ocular reticulum cell sarcoma. Br J Ophthalmol 1980, 64:793-9. | Article | PubMed Abstract | PubMed Full Text

44. Margolis L, Fraser R, Lichter A and Char DH: The role of radiation therapy in the management of ocular reticulum cell sarcoma. Cancer 1980, 45:688-92. | PubMed

45. Isobe K, Ejima Y, Tokumaru S, Shikama N, Suzuki G, Takemoto M, Tsuchida E, Nomura M, Shibamoto $Y$ and Hayabuchi N: Treatment of primary intraocular lymphoma with radiation therapy: a multi-institutional survey in Japan. Leuk Lymphoma 2006, 47:1800-5. | Article | PubMed

46. Hoffman PM, McKelvie P, Hall AJ, Stawell RJ and Santamaria JD: Intraocular lymphoma: a series of 14 patients with clinicopathological features and treatment outcomes. Eye (Lond) 2003, 17:513-21. | Article I PubMed
47. Mikami R, Nakayama H, Goto H, Kimura K, Usui Y, Nogi S, Tajima Y, Okubo M, Kanesaka N, Sugahara S and Tokuuye K: Preliminary results of radiotherapy for primary intraocular non-Hodgkin lymphoma. Leuk Lymphoma 2013. | Article | PubMed

48. Siegel MJ, Dalton J, Friedman AH, Strauchen J and Watson C: Ten-year experience with primary ocular 'reticulum cell sarcoma' (large cell non-Hodgkin's lymphoma). Br J Ophthalmol 1989, 73:342-6. | Article | PubMed Abstract | PubMed Full Text

49. Soussain C, Merle-Beral H, Reux I, Sutton L, Fardeau C, Gerber S, Ben Othman T, Binet JL, Lehoang P and Leblond V: A single-center study of 11 patients with intraocular lymphoma treated with conventional chemotherapy followed by high-dose chemotherapy and autologous bone marrow transplantation in 5 cases. Leuk Lymphoma 1996, 23:33945. | Article | PubMed

50. Sandor V, Stark-Vancs V, Pearson D, Nussenblat R, Whitcup SM, Brouwers P, Patronas N, Heiss J, Jaffe E, deSmet M, Kohler D, Simon R and Wittes R: Phase II trial of chemotherapy alone for primary CNS and intraocular Iymphoma. J Clin Oncol 1998, 16:3000-6. | Article | PubMed

51. Ferreri AJ, Blay JY, Reni M, Pasini F, Gubkin A, Tirelli U, Calderoni A, Zucca E, Cortelazzo S, Chassagne C, Tinguely M, Borisch B, Berger F, Ponzoni M and Cavalli $F$ : Relevance of intraocular involvement in the management of primary central nervous system lymphomas. Ann Oncol 2002, 13:5318. | Article | PubMed

52. Batchelor TT, Kolak G, Ciordia R, Foster CS and Henson JW: High-dose methotrexate for intraocular lymphoma. Clin Cancer Res 2003, 9:711-5. | Article | PubMed

53. Gudauskas G, Ostry A and Rootman J: Concentrations of tritiated methotrexate in ocular compartments, serum and urine after subconjunctival and intravenous injection. Can J Ophthalmol 1980, 15:179-82. | PubMed

54. Henson JW, Yang J and Batchelor T: Intraocular methotrexate level after high-dose intravenous infusion. J Clin Oncol 1999, 17:1329. | Article | PubMed

55. Fishburne BC, Wilson DJ, Rosenbaum JT and Neuwelt EA: Intravitreal methotrexate as an adjunctive treatment of intraocular lymphoma. Arch Ophthalmol 1997, 115:1152-6. | Article | PubMed

56. Smith JR, Rosenbaum JT, Wilson DJ, Doolittle ND, Siegal T, Neuwelt EA and Pe'er J: Role of intravitreal methotrexate in the management of primary central nervous system lymphoma with ocular involvement. Ophthalmology 2002, 109:1709-16. | Article | PubMed

57. Sen HN, Chan CC, Byrnes G, Fariss RN, Nussenblatt RB and Buggage RR: Intravitreal methotrexate resistance in a patient with primary intraocular lymphoma. Ocul Immunol Inflamm 2008, 16:29-33. | Article | PubMed Abstract | PubMed Full Text

58. Bertino JR, Goker E, Gorlick R, Li WW and Banerjee D: Resistance Mechanisms to Methotrexate in Tumors. Oncologist 1996, 1:223-226. Article | PubMed

59. Gorlick R, Cole P, Banerjee D, Longo G, Li WW, Hochhauser D and Bertino JR: Mechanisms of methotrexate resistance in acute leukemia. Decreased transport and polyglutamylation. Adv Exp Med Biol 1999, 457:543-50. | Article | PubMed

60. Fotoohi AK and Albertioni F: Mechanisms of antifolate resistance and methotrexate efficacy in leukemia cells. Leuk Lymphoma 2008, 49:41026. | Article | PubMed

61. Weigand M, Frei E, Graf N, Buchholz B, Wolfrom C, Breuer A and Wiessler M: Mechanisms of resistance to methotrexate in childhood acute lymphoblastic leukemia: circumvention of thymidylate synthase inhibition. J Cancer Res Clin Oncol 1999, 125:513-9. | Article | PubMed

62. Plosker GL and Figgitt DP: Rituximab: a review of its use in nonHodgkin's lymphoma and chronic lymphocytic leukaemia. Drugs 2003, 63:803-43. | Article | PubMed

63. Coiffier B, Lepage E, Briere J, Herbrecht R, Tilly H, Bouabdallah R, Morel P, Van Den Neste E, Salles G, Gaulard P, Reyes F, Lederlin P and Gisselbrecht $\mathrm{C}$ : CHOP chemotherapy plus rituximab compared with $\mathrm{CHOP}$ alone in elderly patients with diffuse large-B-cell lymphoma. N Engl J Med 2002, 346:235-42. | Article | PubMed

64. Batchelor TT, Grossman SA, Mikkelsen T, Ye X, Desideri S and Lesser GJ: Rituximab monotherapy for patients with recurrent primary CNS lymphoma. Neurology 2011, 76:929-30. | Article | PubMed Abstract | PubMed Full Text

65. Rubenstein JL, Combs D, Rosenberg J, Levy A, McDermott M, Damon L, Ignoffo R, Aldape K, Shen A, Lee D, Grillo-Lopez A and Shuman MA: Rituximab therapy for CNS lymphomas: targeting the leptomeningeal 
Hanson et al. Journal of Cancer Therapeutics and Research 2013, http://www.hoajonline.com/journals/pdf/2049-7962-2-15.pdf

compartment. Blood 2003, 101:466-8. | Article | PubMed

66. Feugier P, Virion JM, Tilly H, Haioun C, Marit G, Macro M, Bordessoule D, Recher C, Blanc M, Molina T, Lederlin P and Coiffier B: Incidence and risk factors for central nervous system occurrence in elderly patients with diffuse large-B-cell lymphoma: influence of rituximab. Ann Oncol 2004, 15:129-33. | Article | PubMed

67. Itty S, Olson JH, O'Connell DJ and Pulido JS: Treatment of primary intraocular lymphoma (PIOL) has involved systemic, intravitreal or intrathecal chemotherapy and/or radiotherapy. Retina 2009, 29:415-6. | Article | PubMed

68. Kitzmann AS, Pulido JS, Mohney BG, Baratz KH, Grube T, Marler RJ, Donaldson MJ, O'Neill BP, Johnston PB, Johnson KM, Dixon LE, Salomao DR and Cameron JD: Intraocular use of rituximab. Eye (Lond) 2007, 21:1524-7. | Article | PubMed

69. Kim H, Csaky KG, Chan CC, Bungay PM, Lutz RJ, Dedrick RL, Yuan P, Rosenberg J, Grillo-Lopez AJ, Wilson WH and Robinson MR: The pharmacokinetics of rituximab following an intravitreal injection. Exp Eye Res 2006, 82:760-6. | Article | PubMed

70. Pulido JS, Bakri SJ, Valyi-Nagy T and Shukla D: Rituximab penetrates full-thickness retina in contrast to tissue plasminogen activator control. Retina 2007, 27:1071-3. | Article | PubMed

71. Mineo JF, Scheffer A, Karkoutly C, Nouvel L, Kerdraon O, Trauet J, Bordron A, Dessaint JP, Labalette M, Berthou C and Labalette P: Using human CD20-transfected murine lymphomatous $B$ cells to evaluate the efficacy of intravitreal and intracerebral rituximab injections in mice. Invest Ophthalmol Vis Sci 2008, 49:4738-45. | Article | PubMed

72. Vosganian GS, Boisot S, Hartmann KI, Freeman WR, Sharpe RW, Tripuraneni P and Saven A: Primary intraocular lymphoma: a review. J Neurooncol 2011, 105:127-34. | Article | PubMed

73. Turaka K, Bryan JS, De Souza S, Gordon AJ, Kwong HM, Jr., Ziemianski $\mathrm{MC}$, Reddy R and Sell $\mathrm{CH}$ : Vitreoretinal lymphoma: changing trends in diagnosis and local treatment modalities at a single institution. Clin Lymphoma Myeloma Leuk 2012, 12:412-7. | Article | PubMed

74. Hashida N, Ohguro N, Nishida K: Efficacy and Complications of Intravitreal Rituximab Injection for Treating Primary Vitreoretinal Lymphoma. Translational Vision Science \& Technology 2012, 1(3):1. | Article

75. Chan CC, Fisson S and Bodaghi B: The future of primary intraocular lymphoma (retinal lymphoma). Ocul Immunol Inflamm 2009, 17:375-9. | Article | PubMed Abstract | PubMed Full Text

\section{Citation:}

Hanson JA, Alexandru D and Bota DA: The evaluation and treatment of primary intraocular lymphoma. journal of Cancer Therapeutics and Research 2013, 2:15. http://dx.doi.org/10.7243/2049-7962-2-15 